\title{
Environmental approach to the formation of public spaces of the capital city on the spit of Vasilevskiy Island
}

\author{
Elena Molotkova ${ }^{1, *}$ \\ ${ }^{1}$ St. Petersburg State University of Architecture and Civil Engineering, 2-ya Krasnoarmejskaya, d.4 \\ 190005, St. Petersburg, Russia
}

\begin{abstract}
The paper develops the theses of D.O. Shvidkovsky, interpreting the evolution of the development of St. Petersburg as a successive change in a number of concepts of urban development. Using the example of the Spit of Vasilievsky Island, the main models are highlighted, their radical focus and the overall scale of implementation, characteristic of St. Petersburg, are emphasized. The fundamental discrepancy of the target settings of the urban planning process at three main stages of development of the historical city center is recorded. It is noted that modern urban planning policy does not take into account the damage caused to its landscapes in the 1840-1910s, when the openness and transparency of the ensemble of central squares were lost, and the Collegiate Square on the Spit was liquidated. The relevance of a return to a multifactorial environmental approach in the formation of urban open spaces today is emphasized.
\end{abstract}

\section{Introduction}

Assessing the features of the formation of St. Petersburg, D.O. Shvidkovsky notes that "in the mind of the sovereign, the idea of Petersburg changed more than once, and he began to found the city anew, different than before ... Later, during the reign of Anna Ioannovna and Elizaveta Petrovna, Catherine II and Alexander I, something similar also happened" [1]. The proposed paper discusses the features and highlights the specifics of each of the main stages of the evolution of the urban organism of St. Petersburg, taking into account the changing goals.

\section{Subject, tasks and methods}

The methodological basis of the study is an integrated approach, which includes the study and analysis of information from literary and Internet sources related to the urban

\footnotetext{
*Corresonding author: elena2255@yandex.ru
} 
development of St. Petersburg. The analysis of graphic materials - plans of the Spit of Vasilievsky Island in different periods of city development - is carried out.

Using the example of the Spit of Vasilievsky Island, the main models are highlighted, their radical focus and the overall scale of implementation, characteristic of St. Petersburg, are emphasized. The fundamental discrepancy of the target settings of the urban planning process at three main stages of development of the historical city center is recorded.

\section{Research results and Discussion}

\subsection{3-1714}

Obviously, at the initial stage of the formation of the development of St. Petersburg on the northern bank of the Neva river, the idea of Peter I about its functional role dominated. The center of the city was the square appeared close to the fortress. Along with the facilities that responded to the primary needs of the townspeople (market, row of shops, tavern, and then the church) and were typical of any newly emerging settlement, administrative buildings of colleges, the Senate and Synod buildings appeared here, as well as the port and customs typical of coastal cities [2]. The full-scale sketch of the 1710 s indicates that during these years, the external appearance of St. Petersburg was not given much attention, and the unregulated development looked disordered, unpresentable (Fig. 1).

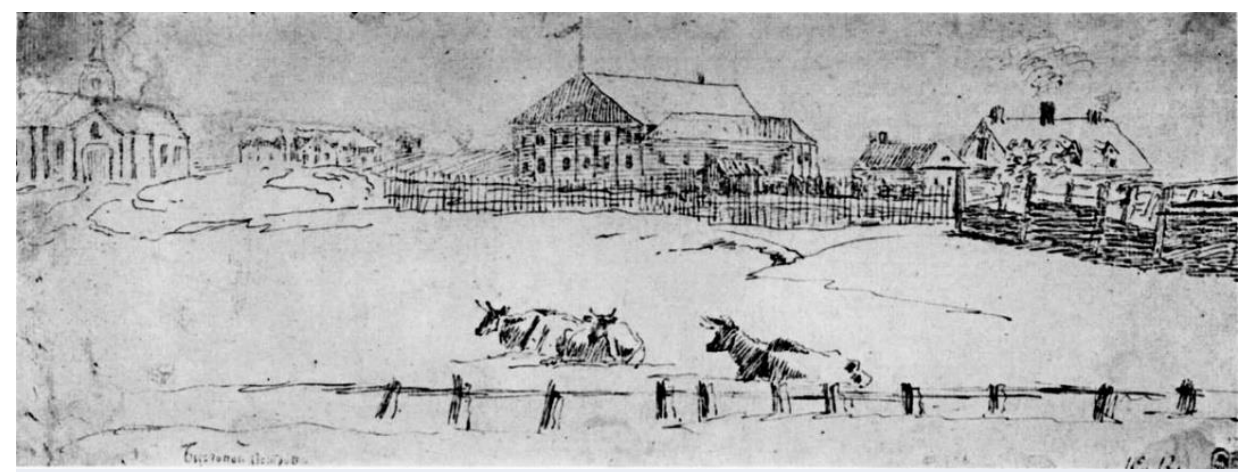

Fig. 1. Troitskaya Square (F. Vasiliev, 1710s).

\subsection{4}

In 1714 Peter the Great began the construction of the Russian capital anew, and began the development of Vasilievsky Island. The vast territory here was only fragmentarily affected by urbanization processes and left the possibility of implementing any urban planning concepts. The model, which was embodied in the Spit district, combined the already tested functional component with the regular scheme of the rigid urban planning composition drawn by Peter I in the sketch of the capital city on Kotlin island.

The development progress of Vasilievsky Island was similar to the actions of European sailors who created strongholds on the overseas shores during the era of great geographical discoveries [3]. The primary and key task was the formation of a pre-port city square - the epicenter of urban life [4]. Peter I also attached particular importance to the square on the Spit. The pace of its active development outstripped the development of residential neighborhoods, and the emperor personally delved into all the details that could affect the 
nature of its use. The founder of St. Petersburg not only built buildings, formed a network of streets and canals - he predicted urban life: "The tsar, of course, was thinking not about an abstract city, but about life in it, arranged to his liking. ... Peter the Great saw the settlement itself as huge, active, bustling with all kinds of activity and trade...” [1]. The area was considered as the central part of the urban planning system, which ensured the active use of the entire developed space.

Tools were used that are now regarded as signs of an environmental approach. In the space of the square, objects of various functional purposes were combined: the administrative building of the Twelve Collegia, the Kunstkamera museum building, the palace of Tsarina Praskovia Fedorovna transferred to the Academy of Sciences, the Gostiny Dvor. The cathedral located in its center and benches along the perimeter should attract the townspeople to the square (Fig. 2). The record of the Chancellery of the Emperor made in 1724 has been preserved: "The intention of E. I. V. was to have the shops of Gostiny Dvor around that square and under the collegiums in the lower apartment on the window side" [5]. At the direction of Peter I, galleries with benches located behind them stretched along the first floor of all 12 colleges in order to use the 400 -meter front of the main administrative building of the empire for the benefit of citizens.

Attention to the utilitarian component of the urban environment was manifested at different levels. It was important to ensure a convenient connection of the central square with the residential area. The obstacle was created by the estate of governor general A.D. Menshikov, stretching across the island from one coast to the other. It was planned to lay a communication corridor through it - a continuation of the main city highway, which was supposed to be the shortest route from the square to the residential quarters.

The evidence of the pragmatic approach of Peter I to the formation of a living environment has been preserved. Judging by the copy made by the cabinet-secretary of the emperor, the attention of the architects was drawn to the utilitarian qualities of the created projects: "According to Le Blond drawings, in all the buildings, and especially in the Petersburg houses, the windows are big and the gaps between them are small. Declare him to make smaller windows in bedrooms, but in the living rooms - as he wants. Here is not a French climate" [5]. Resource constraints were taken into account. Mass development had to be made of wood, using a hut (half-timbered) technology, but for key buildings, local or even imported brick was used.

In 1716, master of landscape architecture from Paris J.-B. Le Blond were invited. He was appointed general architect and commissioned to develop a general plan of the Russian capital. It can be assumed that Peter I was counting on the contribution of an experienced architect in solving compositional and artistic problems. However, the development of Le Blond did not cause his positive reaction. "Peter the Great did not literally used Le Blond's plan and neglected it, as well as the entire French urban theory" [1].

Peter I succeeded in only partially implementing the plan. He died suddenly in 1725 , and construction work on Vasilievsky Island began to subside. It was possible to complete the buildings of the Twelve Collegia and the Gostiny Dvor, and a swampy lowland remains on the site of the square. In the 1730s, the Admiralty side became the city center. Vasilievsky Island was "for the great cost, and for many difficulties $<\ldots>$ left to build up and appointed a suburb of the city" [6]. Summing up the results of this stage of development of St. Petersburg on Vasilievsky Island, it can be emphasized that it was characterized by a combination of artistic-aesthetic and utilitarian-applied goals. 

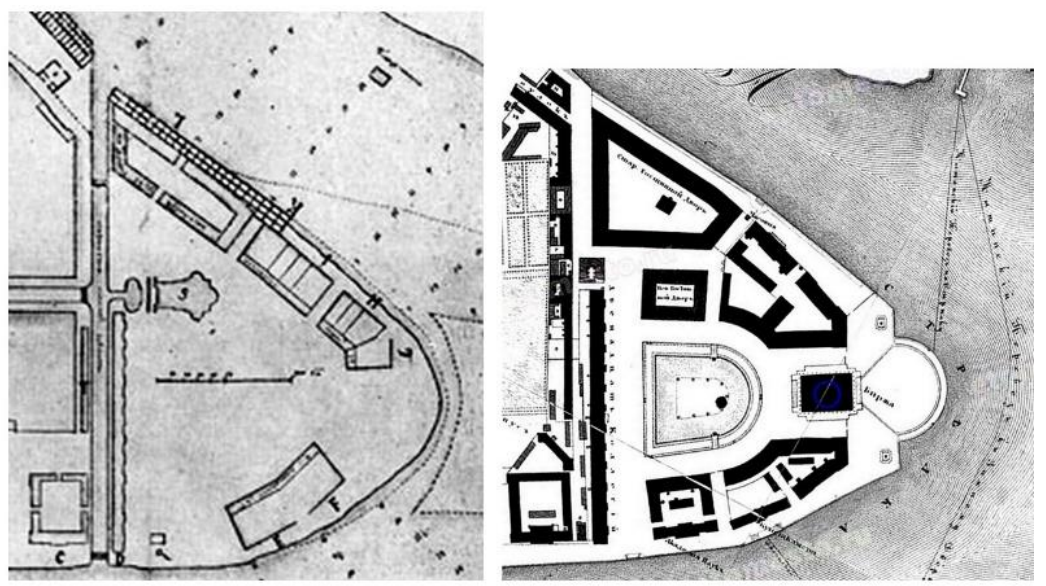

Fig. 2. The Spit of Vasilievsky Island. On the left is a variant of the 1720s [5], on the right - the 1830s [7].

\section{$3.31730 \mathrm{~s}-1830 \mathrm{~s}$}

"Under the Empress Anna Ioannovna, Petersburg was a second time born by the efforts of Eropkin and his colleagues ... Eropkin proceeded to redevelop the capital of Russia on other grounds than the architects of the time of Peter the Great" [1]. The focus was on emotional and aesthetic attitudes. "A space of the city was created, which was destined to exist for centuries and convey the splendor of baroque planning compositions even when they will subsequently be dressed in solemn and strict forms of classicism" [1]. Considerations of utilitarianism, convenience, and applied value fade into the background. This area of urban development was supported by both Catherine II, and Alexander I.

The main efforts of the second half of the XVIII century were aimed at transforming the main channels of the Neva Delta and settling the territories adjacent to them. Space of squares began to attract attention only at the beginning of the XIX century. Even in 1794, a contemporary just indifferently enumerated them, at times noting a low level of improvement [8].

Two decades have passed, and a magnificent system of huge open, clearly defined spaces appears in the center of the city. It reveals a wide view of "everything that Petersburg has majestic and beautiful: the Neva, the Winter Palace, magnificent Palace square, forming a semicircle, Nevsky Prospect, Isakievskaya Square, the Horse Guards Manege, which resembles Parthenon, the charming building by Quarenghi, the Senate, the monument to Peter I and again the Neva with its embankments!" [9].

The Spit lies a little to the side, and its transformation is slightly delayed. Although since 1753, the area conceived by Peter I has been officially called Collegiate Square, the people continue to call the undeveloped space Admiralteysky Meadow. In 1794, the Spit's center still remains "a large irregular, still unpaved, partly marshy area surrounded by the buildings of the Academy of Sciences, State Collegia, the Exchange and Customs barns" [8]. In 1805, the draft of its transformation, drawn up by A.D. Zakharov and J.-F. Thomas de Thomon, was established. In 1816, the Exchange building was inaugurated. In 1825 , the "Commission for the completion of buildings on Birzhevaya Square" was created, which included I.F. Lukini, who served in the customs department. Under his leadership, the reconstruction of the Old Gostiny Dvor was first carried out according to the project of K.I. Rossi, and by 1832, they built up the entire contour of Collegiate Square. 
An open urban space was formed, comparable to Palace Square in St. Petersburg or Place Vendome in Paris in its geometric parameters and artistic and compositional qualities (Fig. 2). The appearance of the square combines the style of Peter the Great Baroque and Alexander Empire, the creative ideas of famous St. Petersburg architects - D. Trezzini, J. Quarenghi, A.D. Zakharov, Tomas de Thomon, I.F. Lukini. "One of the most beautiful ensembles of old Petersburg" appeared [10]. Collegiate Square became part of the grandiose urban planning ensemble that developed in the center of St. Petersburg by the beginning of the 1840s. A feature of this unique landscape was "a single continuous open space formed by water areas, squares, avenues, streets, parks" [11]. It can be concluded that the main area of the city's development in the 1730-1830s was the solution of compositional and aesthetic problems, which led to the formation of a city-planning ensemble unique in landscape characteristics.

\section{$3.41840 \mathrm{~s}-1910 \mathrm{~s}$}

Modern researchers associate fundamental changes in the development concept of St. Petersburg with the name of Nikolai I: "His reign marked a turning point in the history of the country's architectural and urban planning activities". The start was given to the rejection of "the fundamental principles of architectural and urban planning policies laid down in the first quarter of the XVIII century" [12]. At first, the influence of the aesthetics of Russian classicism remained, its "state version" appeared - Nikolaevsky Empire [13] but then a new concept for the development of the city will gain strength. In the early $1840 \mathrm{~s}$, the Betancourt committee, which dealt with the "exterior beauty" of St. Petersburg, was dissolved, and Nikolai I placed a new theater-circus building in the middle of Theater Square and became the initiator of the sealing development. However, he did not touch the spaces of the central squares, since he considered them an ideal place for solemn military parades.

After the death of Nikolai I, most of the deserted representative territories were landscaped (the Alexander Garden was opened in 1873, and the Guard Mounting Plot was turned into a Private Garden in 1896), which increased their utilization rate and solved urgent sanitary and hygienic problems. However, at the same time, architectural and urban considerations were completely ignored, and soon overgrown arrays of high-standing plantings radically changed the nature of the historical center.

The life of the Collegiate Square did not develop as Peter I dreamed. The extensive geometrically defined space created in the 1830 s corresponded to his regular city model, but did not provide the kind of animation that the founder of St. Petersburg dreamed about. The shops with galleries planned by D. Trezzini never appeared; instead, behind the representative monumental facades along the contour of the square, there were customs warehouses - temporary storage warehouses. Most of the area ceased to be public space, but turned out to be the official territory of the port, temporary warehouses were built here or small sheds were erected. Citizens were allowed here only occasionally in those spring days, when there was a sale of outlandish birds and animals brought by the first vessels arrived [14].

The plan of 1891 records that the entire center of the square is fenced off and renamed to Customs Square. In 1897-1904, this part of the city ceased to be open space - the square area was filled with the buildings of the Imperial Clinical Institute of Obstetrics named after D.O. Ott (Fig. 3).

The review shows that the development of open public spaces of the historical center in the second half of the XIX century was determined by pragmatic considerations, and the 
undertaken city-forming actions did not contribute to the preservation of their landscape characteristics.
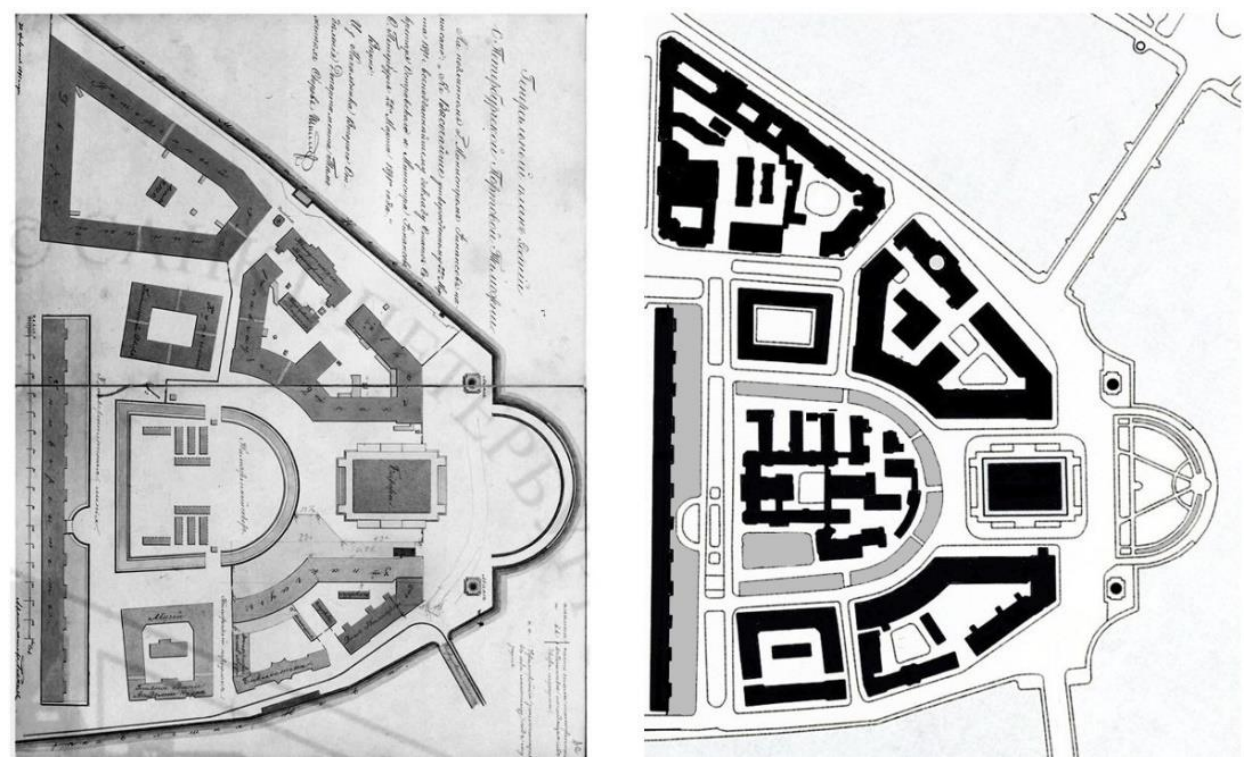

Fig. 3. On the left is Collegiate Square in 1891 [15], on the right is the current state [7].

The overgrown trees covered the main facade of the Admiralty eliminated the visual connections between the center's squares and the Neva. In order to overcome the negative results of such reconstruction, already in 1890, on the instructions of Alexander III, tall trees were cut down in that part of the Alexander Garden where the greenery covered the view of the Bronze Horseman. Architectural criticism welcomed the fruitfulness of the administrative decision and insisted on the continuation of such adjustments $[13,16,17]$.

However, the World War broke out, then a revolution followed. The formation of the urban environment of the historical center "ended (or stopped) a hundred years ago, after which it did not undergo drastic changes" [18]. Therefore, the criticism does not stop, calling the situation at the beginning of the XX century "urban barbarism" $[19,20]$.

\section{Conclusions}

A - the study showed how various concepts determined the development of the urban environment of St. Petersburg in the first two centuries of the city's existence. Table 1 reveals the change of goals, the drama of the conflicts that arose and, as a result, the radicalism of the reconstructions.

B - the data presented allow stating a lack of objectivity in the modern assessment of landscapes of the historical center. Already a hundred years ago, the suffered losses were pointed out, and it was stated that "for the modern resident of Petersburg, the peculiar architectural charm that was clearly visible in the old days is not well understood" (Stolpyansky, 1918), that "most residents of Petersburg do not suspect the beauty ... of an incomparable creation of Russian genius" [16]. It seems that in our time, the situation has worsened, and experts often do not remember the losses suffered, are quite satisfied with the completeness and perfection of the reconstructed urban environment [18]. These key provisions are shared at the official level [21]. 
Table 1. Target settings at various stages of urban development.

\begin{tabular}{|c|c|c|c|}
\hline \multirow[t]{2}{*}{ Target settings } & \multicolumn{3}{|c|}{ Stages of urban development } \\
\hline & $\begin{array}{l}1714- \\
1730\end{array}$ & $\begin{array}{l}1730 \\
1830\end{array}$ & $\begin{array}{l}1840- \\
1918\end{array}$ \\
\hline $\begin{array}{l}\text { Spatial (landscape, compositional } \\
\text { and aesthetic) }\end{array}$ & & & \\
\hline Functional (applied, utilitarian) & & & \\
\hline
\end{tabular}

The St. Petersburg concept of preservation of cultural heritage attaches exceptional importance to the "spatial planning framework" of the historical center, and to the "species channels of perception of dominants, ensembles and environmental development", considers their changes impossible in modern conditions. At the same time, radical transformations of these key indicators at the end of the XIX century, which were pointed out by the architectural criticism of the past and which are emphasized by modern urban planning science [12], are ignored. Urban toponomy suggests counting as squares (open public spaces) those sections of the urban territory that have lost transparency and are filled with a dense array of overgrown tall greenery.

The imperfection of the system, which excludes an objective assessment of the current situation and does not consider the prospects of restoring the landscape potential of the historical center that suffered at the end of the XIX century, is obvious.

$\mathrm{C}$ - the modern urban planning practice of St. Petersburg ignores the potential of the environmental approach, which distinguishes the beginning of the XVIII century, but turned out to be unclaimed at the next stages of the city development. The laying of a new WHSD transport line along the western part of Vasilievsky Island [22] became paradoxical. Its route was laid a few kilometers from the core of the historic center, but technical solutions specific to suburban autobahns were used.

\section{References}

1. D.O. Shvidkovsky The great city of Peter the Great "Our Heritage" 66, 4-29 (2003)

2. V.D. Privalov Kamennoostrovsky prospect (2005)

3. A.F. Eremeeva, L.P. Lavrov, F.V. Perov, Kommersant Nauka, 29-31 (October, 2018)

4. E.I. Kirichenko, General history of architecture in 12 volumes (1969)

5. E.A. Borisova The work of Domenico Trezzini on the planning and development of the Spit of Vasilievsky Island in St. Petersburg (1973)

6. Complete collection of laws of the Russian Empire 10, 115 (1737-1739)

7. S.V. Sementsov, A.D. Margolis, St. Petersburg. Plans and maps (2004)

8. I.G. Georgi, Description of the Russian-imperial capital city of St. Petersburg and memorials in the vicinity thereof 3, (1794)

9. K.N. Batyushkov, Experiments in poetry and prose (1977)

10. V.G. Lisovsky JSC Slavia, 416 (2004)

11. D. Shvidkovsky, Russian architecture and the West. New Haven (2007)

12. E.I. Kirichenko, M.V. Nashchekina, Urban planning of Russia in the middle of the XIXearly XX centuries. Russian urban planning art 3 (2001-2010) 
13. I.E. Grabar History of Russian art III, Architecture. Petersburg architecture in the XVIII - the first third of the XIX century (1910)

14. E.N. Gruzdeva, Zoological Museum on the Spit of Vasilievsky Island (according to the documents of the archive of the Russian Academy of Sciences, St. Petersburg branch)

15. P.N. Stolyansky, How St. Petersburg arose, was founded and grew (1918)

16. V.Ya. Kurbatov, Petersburg: An artistic and historical essay and review of the artistic wealth of the capital (1913)

17. G.K. Lukomsky, Apollon 11 (1910)

18. B.M. Kirikov, Architecture of Petersburg-Leningrad (2014)

19. M. Roslavlev Old Petersburg-New Leningrad, PH of Academy of Arts (1928)

20. P.N. Stolyansky Old Petersburg. Admiralty Island. Garden of Workers: a historical and artistic essay (1923)

21. TSN 30-306-2002, Reconstruction and development of historically developed areas of St. Petersburg, 71 (2003)

22. L. Lavrov, E. Molotkova, Architecture and Engineering 4(2), 40-51 (2019). DOI: https://doi.org/10.23968/2500-0055-2019-4-2-40-52 